\title{
EXPRESSION OF FLAGELLIN FIjB DERIVED FROM Salmonella enterica SEROVAR TYPHIMURIUM IN Escherichia coli BL21
}

\author{
Do Thi Huyen, Le Quynh Giang, Truong Nam Hai* \\ Institute of Biotechnology, Vietnam Academy of Science and Technology, *tnhai@ibt.ac.vn
}

\begin{abstract}
Flagellin FljB composes flagellar antigen (H:1,2) of $S$. Typhimurium. This kind of antigen increases immunogenicity of any conjugated antigen upon administration. Thus, it is supposed to have an enormous potentiality for vaccine development against bacterial infections and cancer diseases. $f l j B$ gene (1515 nucleotides) coding for mature FljB was amplified by PCR from genomic DNA of $S$. Typhimurium and inserted into pET32a(+) for expression in $E$. coli BL21. The protein FljB was well expressed under the fusion form with Trx, S-tag at $\mathrm{N}$ terminal and hexahistidine at $\mathrm{C}$ terminal, thus the recombinant protein was abbreviated to TrxFljB. Study on the impact of temperature on the gene expression showed that TrxFljB was synthesized at lower level at $37^{\circ} \mathrm{C}$ comparing to the levels at $22^{\circ} \mathrm{C}$ and $25^{\circ} \mathrm{C} .13 \%$ of the protein synthesized at $37^{\circ} \mathrm{C}$ was inclusion body. Lower temperatures used during induction phase increased the solubility of the recombinant protein. About $97 \%$ of $\operatorname{TrxFljB}$ synthesized at $25^{\circ} \mathrm{C}$ was soluble. IPTG concentration had a strong effect on the growth of freshly transformed cells but did not affect on the growth of stored and re-cultivated cells. The increase of IPTG concentration resulted in the decrease of the growth of freshly transformed cells and the TrxFljB productivity. However, $0.05 \mathrm{mM} \mathrm{IPTG}$ concentration was found to gain the full TrxFljB expression. TrxFljB productivity declined during storage of cells at $4^{\circ} \mathrm{C}$ and re-cultivation. At optimal condition, volumetric productivity of $\operatorname{TrxFljB}$ was about $300 \mathrm{mg} / 1$ broth.
\end{abstract}

Keywords: Escherichia coli BL21, fljB, pET32a(+), S. Typhimurium, recombinant protein.

\section{INTRODUCTION}

Flagellar antigen had been characterized more than 80 years ago and it is composed of a single protein known as flagellin. Recently, this antigen from Salmonella has been paid much attention as it increases immunogenicity of any conjugated antigen upon administration. Thus, it is supposed to have an enormous potentiality for vaccine development against bacterial infections and cancer diseases [16]. In cancer diseases, tumor develops because immune system of individuals can not recognize the tumor specific antigens and thus the tumor antigens are not effective in inducing maturation of antigen presenting cells (APC). As a result, the APCs do not express sufficient co-stimulatory molecules to activate $\mathrm{T}$ cells proliferation and $\mathrm{T}$ cell engaged by such APC become tolerant to the antigen presented. Flagellin was evaluated to be capable of inhibiting tolerant when it is administered in conjunction with tolerogenic antigen [16].

In Vietnam, Salmonella enterica serovar
Typhimurium ( $S$ I 4,$5 ; \mathrm{i}, 12: 1,2)$ is a dominant serotype causing food poisoning disease in human [20]. The majority of outbreaks are traced back to foods containing raw or undercooked poultry products [18]. Thus immunization of chickens with vaccine is an effective way to reduce food-born illness in human. Currently, in poultry two kinds of vaccines used against Salmonella are live attenuated and inactivated vaccines. Live attenuated vaccine, which was developed by disruption of virulent genes of wild strains, are considered to have the highest vaccine potential. But attenuated vaccine strains show genetic instabilities and the virulent genes revert with the virulent features [1]. Thus these vaccines still retain virulence to other hosts and do not decrease egg contamination [4]. Inactivated vaccines take higher advantage of safety for poultry and environment and capacity to transfer maternal Salmonella antibodies through eggs. The maternal antibodies in eggs can protect young chickens from Salmonella infection in high challenge environments [2]. 
However, the inactivated vaccines poorly stimulate immunity in poultry. Therefore, development of more effective, safe vaccines is required to eliminate Salmonella from chickens.

In recent years, evidences for immunogenicity of flagellin have accumulated. Flagellin stimulates both innate and adaptive immune responses in poultry. In adaptive immune response, flagellin induces both humoral immunity to protect poultry from Salmonella invasion through intestinal tract and cell-mediated immunity to kill the bacterial cells $[3,5,7,8,9,10,11,12,13,15,19]$. Furthermore, the maternal antibodies in eggs which protect young chickens from Salmonella were demonstrated to be induced by flagellin in inactivated vaccines [2]. Thus, flagellin is a good candidate for development of sub-unit recombinant vaccine $[17,18]$.

$S$. Typhimurium ( $S$ I 4,$5 ; \mathrm{i}, 12: 1,2)$ carries two distinct flagellin genes $(f l i C$ and $f l j B)$ and through phase variation it expresses two antigenically different flagella on its surface. These antigens share conserved $\mathrm{N}$ - and $\mathrm{C}$ terminal domains or regions I, II, III and VII, VIII which give rise to cross-reactions between $S$. Typhimurium and other Salmonella serotypes and members of Enterobacteriacea in serological tests based on whole purified flagellum antigen. However, regions IV, V, VI of FliC and FljB induce the production of specific antibodies in infected host [21]. By phase variation, bacteria escape from antibodies in environment and survive [12].

In order to develop an effective component vaccine for poultry against $S$. Typhimurium, we expressed $f l j B$ gene coding for mature flagellin composing $\mathrm{H}: 1,2$ antigen in $E$. coli. Protein expression level and protein stability was assessed.

\section{MATERIALS AND METHODS}

Salmonella serovar Typhimurium was kindly provided by National Veterinary Institute. The strain originated as source of $f l j B$ gene. E. coli $\mathrm{DH} 5 \alpha$ strain [end Al rec Al hsd R17 sup E44 gyp A96 thi-1 rel A1 Alac U169 ( $\phi 80$ lac $Z M$ 15)] was purchased from
Invitrogen, and used as the host for gene manipulation. E. coli BL21 strain [F-omp hsd $S B(r B m B) g a l d c m$ (DE3) plys $S$ (Caml)] was purchased from Novagen and used as the host for expression of heterologous protein. Plasmids pCR2.1 (Invitrogen) and pET32a (+) (Novagen) were used as cloning and expression vectors, respectively.

Restriction enzymes and T4 DNA ligase, DNA ladder, standard proteins, dNTP and isopropyl-beta-dithiogalactopyranoside (IPTG) were purchased from New England Biolabs and Fermentas. Taq DNA polymerase and chemical reagents for PCR were purchased from PerkinElmer, USA. Primers were synthesized by Invitrogen, England.

$S$. Typhimurium antibodies, E. coli antibodies were produced in SPF chickens at Swedish Veterinary Animals, Sweden.

\section{Recombinant DNA techniques}

Restriction enzyme digestions, ligation and DNA manipulations were performed by standard procedures [14].

Based on $f l j B$ sequence in the GenBank database (Accession No. AF045151), a pair of primer that was used for $\mathrm{flj} B$ gene amplification was designed as following:

fljBf: 5' TATACCATGGATGCACAAGTAAT CAACACTAAC 3' fljBr: 5, TATACTCGAGACGTAACAGAGA
CAGCACGTTC 3'

Restriction sequences of Nco I and Xho I were incorporated into the 5 ' end of the forward and reverse primer sequences, respectively (bold and underline letters). PCR was performed with the hot start method. In a total volume of $25 \mu \mathrm{l}$ containing $1 \times$ PCR buffer, 1 pmol of each primer, $1 \mathrm{mM}$ of each of dNTP (deoxynucleoside triphosphate), $1 \mathrm{mM}$ of $\mathrm{MgCl}_{2}, 1 \mathrm{U}$ of Taq polymerase and about $200 \mathrm{ng}$ of chromosomal DNA as template which was prepared as Do Thi Huyen et al. (2003) [10]. The PCR condition was initial denaturation at $94^{\circ} \mathrm{C}$ for $3 \mathrm{~min}$, each cycle of amplification consisted of denaturation at $94^{\circ} \mathrm{C}$ for $1 \mathrm{~min}$, annealing at $55^{\circ} \mathrm{C}$ for $1 \mathrm{~min}$ and polymerization at $72^{\circ} \mathrm{C}$ for $1 \mathrm{~min} 30 \mathrm{sec}$ and further 
polymerization for $7 \mathrm{~min}$ after 25 PCR cycles. PCR products were analysed by electrophoresis in agarose gel.

\section{Construction of expression vector $p E T 32 f l j B$}

The PCR products were inserted into cloning vector pCR2.1 for generating pCRfljB. To limit the number of sequencing samples, in the cloning vector, the gene was first confirmed by restriction enzymes. Afterwards, $f l j B$ gene was double digested with Nco I and Xho I and the fragment was purified from agarose gel using DNA purification kit (Quiagen) and inserted into pET32a(+) vector containing compatible ends. The ligation product was transformed into E. coli $\mathrm{DH} 5 \alpha$. In pET32a(+), $f l j B$ was fused with the genes coding for thioredoxin, S-tag, hexahistidine at 5' end and hexahistidine at 3' end, which help in recombinant protein purification and quantification. The novel obtained vector pET32fljB was transformed into E. coli BL21 cells for protein expression.

Expression of fljB gene in E. coli and purification of recombinant protein

The recombinant strain was incubated in 5 $\mathrm{ml} \mathrm{LB}$ containing $100 \mu \mathrm{g} / \mathrm{ml}$ ampicillin (LBA) at $37^{\circ} \mathrm{C}, 200 \mathrm{rpm}$ until the cell density at 600 $\mathrm{nm}$ reached to 0.6-1. The samples were kept at $4^{\circ} \mathrm{C}$ overnight then induced with IPTG at the suitable concentration for production of the recombinant protein. The cells were incubated at $200 \mathrm{rpm}$ for 5 hours at 25 or $30^{\circ} \mathrm{C}$. Then $E$. coli cells were harvested by centrifugation at $13000 \mathrm{rpm}$ for $10 \mathrm{~min}$. The pellets were suspended to OD600 of 10 with distill water, then the total and soluble fractions were analyzed by standard sodium dodecyl sulfate polyacrylamide gel electrophoresis (SDSPAGE). The soluble proteins were prepared by heat shock at $60^{\circ} \mathrm{C}$ and sonication then centrifugation. The clear supernatants were collected for soluble protein analysis and for protein purification.

For TrxFljB purification, the collected supernatant was diluted 2 times by binding buffer $(20 \mathrm{mM}$ sodium phosphate, $300 \mathrm{mM}$ sodium chloride, $\mathrm{pH} 7,4)$ then suplied into Histag chromatography column equilibrated with the binding buffer. The column was washed with 10 column's volumes of wash buffer (20 $\mathrm{mM}$ sodium phosphate, $300 \mathrm{mM}$ sodium chloride, 0-100 mM imidazol, $\mathrm{pH} 7,4)$. The recombinant protein was eluted in the buffer containing $400 \mathrm{mM}$ imidazol.

\section{Analysis of product}

The concentration of the recombinant protein was determined by S.tag Rapid Assay Kit (Novagen) through S-tag fused with the protein and by analysis of protein on SDSPAGE gel. For determination of amount recombinant by analysis of protein on SDSPAGE gel, firstly, concentration of purified TrxFljB was determined by S.tag Rapid Assay Kit. One $\mu \mathrm{g}$ of purified TrxFljB was separated in SDS-PAGE gel. The images of SDS-PAGE gels were scanned by VersaDoc Imaging system Model 4000 (Bio-Rad, USA). Density of TrxFljB band and standard proteins were analyzed by Quantity One software, Version 4.6.1 (Bio-Rad, USA). The density of $2.5 \mu \mathrm{g}$ TrxFljB on the gel was equivalent to 1 band of albumin $(66 \mathrm{kDa})$ derived from $6 \mu$ of standard proteins purchased from Amersham. Thus, base on protein marker on gel, concentration of TrxFljB was estimated.

Recombinant protein purification: After.

\section{RESULTS AND DISCUSSION}

\section{Construction of expression vector pET32fljB}

Entire $f l j B$ gene coding for mature flagellin composing $\mathrm{H}: 1,2$ of $S$. Typhimurium was amplified by PCR from chromosomal DNA. The PCR product was $1.5 \mathrm{~kb}$, it was the same length of $f l j B$ gene in the Genbank. After insertion into pCR2.1, the gene was checked for EcoR I restriction site (data not shown). From sequencing, the cloned $f l j B$ gene consisted of 1515 nucleotide with $100 \%$ homology with $f l j B$ (Genebank No. AF045151) and coded for a protein of 505 amino acids. Comparison of deduced amino acids from cloned $f l j B$, fliC genes of $S$. Typhimurium strain showed that amino acid residues 1-180, 416-505 of FljB were $99 \%$ identical with respective regions in FliC of this $S$. Typhimurium strain (the result 
not showed). These regions are located on I, II, VIII regions of FljB [21] as the same as in flagellins of all members of Enterobacteriacea. This $\mathrm{N}$ terminal protein fraction plays a very important role in immunogenicity of antigen because it is recognized by Toll like 5 (TLR-5) receptor which induces immune responses in infected host 13. Amino acid sequence from residue 314 to 414 of $\mathrm{FljB}$ was $68 \%$ homologous with corresponding region of FliC, the remaining region showed only $42 \%$ homology between FljB and FliC. This difference induces the production of different antigen-specific antibodies in animals. The difference in amino sequence of FliC and FljB pointed up the necessary to express $f l j B$ parallel with fliC expression for Salmonella recombinant vaccine development.

\section{Expression of $f l j B$ gene in $E$. coli}

Based on Expasy sorfware ((http://www.expasy.ch/tools/), the molecular weight of recombinant protein was predicted. In theory, after fusing with thioredoxin located in pET32a(+), the complete recombinant protein (TrxFljB) was $70 \mathrm{kDa}$ and $\mathrm{pI} 5.13$ and also the expression product, TrxFljB (fig. 1) was 70 $\mathrm{kDa}$. Because antibody against $\mathrm{FljB}$ is not available in commercial, and the other hand, S. Typhimurium and E. coli are the members of Enterobacteriacea family, they share so much in phenotype and genotype. Thus it is no worth to use $S$. Typhimurium antibodies for identification of expressed FljB from total protein extract of recombinant E. coli strain. The volumetric productivity of the strain was about $200 \mathrm{mg}$ of TrxFljB per liter of broth.

In 2004, Cuadros expressed FliC as fusion protein with EGFP (enhanced green fluorescent protein) which was stable from protease degradation and the fused EGFP (27 kDa, higher than thioredoxin in this study) did not affect the immunogenicity of the recombinant protein. The recombinant FliC had ability to activate maturation of antigen presenting cells and proliferation of cytokines in animals.

\section{Selection of expression conditions}

\section{Effect of cultivation temperature}

It is well-known that the temperature is an important parameter in recombinant protein expression and especially for soluble protein fraction. Many studies showed that the use of low cultivation temperature was effective in improving the solubility of structurally and functionally unrelated target protein. In this study, the recombinant E. coli BL21 strain carrying pET32fljB was cultivated in the presence of $0.4 \mathrm{mM}$ IPTG at different temperatures: $22,25,30,37^{\circ} \mathrm{C}$ for 5 hours. The soluble fractions were harvested after heatshock and sonication of the cultured cells and then the pellets were used for insoluble fractions analysis. The results (Fig. 2) revealed that TrxFljB was expressed at high level when temperature spectrum was under $30^{\circ} \mathrm{C}$ and was sensitive with temperature at $37^{\circ} \mathrm{C}$. It is known that, $37^{\circ} \mathrm{C}$ is optimal temperature for $E$. coli growth and synthesis of many proteases, and $37^{\circ} \mathrm{C}$ also is suitable temperature for protease activities. Thus, the results may reveal that TrxFljB was synthesized at $37^{\circ} \mathrm{C}$ but digested by host proteases.

Normally, a protein expressed at high level in E. coli, and a part of it usually is inclusion body, that normally does not ensure biofunction. Interestingly, the most TrxFljB was soluble (table 1). At $25^{\circ} \mathrm{C}$, percentage of soluble TrxFljB to total TrxFljB was the highest (97\%). The increase of temperature during induction caused a decrease of soluble recombinant protein production. At $37^{\circ} \mathrm{C}, 13 \%$ of $\operatorname{TrxFljB}$ produced was inclusion body.

Effect of IPTG concentrations on TrxFljB expression level

Table 1. Impact of temperature on $\mathrm{TrxFljB}$ production

\begin{tabular}{lcccc}
\hline Temperature $\left({ }^{\circ} \mathrm{C}\right)$ & 22 & 25 & 30 & 37 \\
TrxFljB $(\mathrm{mg} / \mathrm{l}$ broth) & 268 & 267 & 195 & 116 \\
Soluble TrxFljB/ Total TrxFljB $(\%)$ & 95 & 97 & 94 & 87 \\
\hline
\end{tabular}




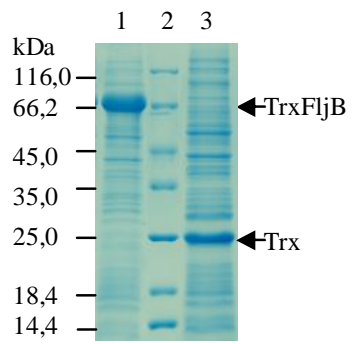

Fig. 1. SDS-PAGE analysis of total protein extraction from the recombinant $E$. coli

1. Strain harboring pET32fljB; 2. Standard proteins; 3. Strain harboring $\mathrm{pET} 32 \mathrm{a}(+)$.

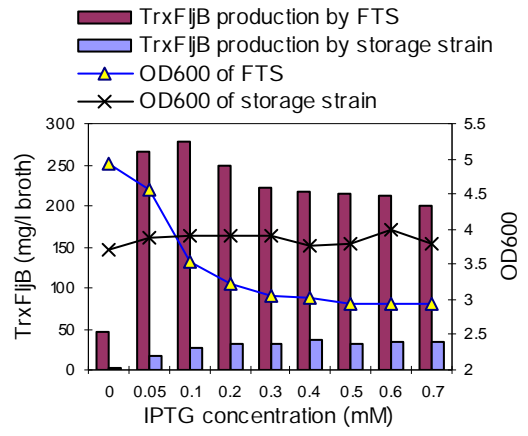

Fig. 3. Effects of IPTG concentration on the growth of E. coli BL21 harboring pET32fljB, and on the TrxFljB production. FTS: freshly transformed strain.

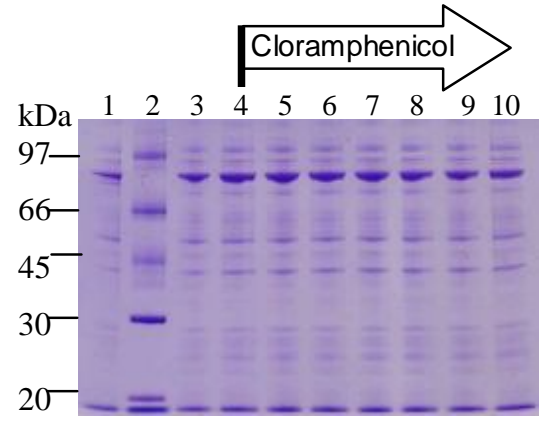

Fig. 5. Impact of proteolysis on the accumulation of the soluble TrxFljB

$1,3,4$ : the samples were harvested at $2,3,4$ hours of induction; 5-10: The samples were harvested at $4.5 ; 5 ; 5.5 ; 6 ; 6.5 ; 7$ hours of induction; 2 : Standard proteins (Amersham).

The foreign protein expression in pET32a(+) was triggered by addition of IPTG into the culture medium. Concentration of IPTG

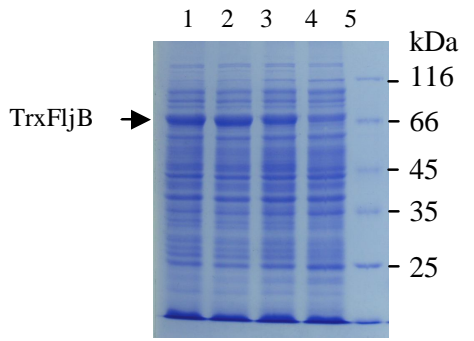

Fig. 2. SDS-PAGE analysis of total protein extractions from the recombinant E. coli BL21 strain cultivated in induction culture at different temperatures. 1-4: $22,25,30,37^{\circ} \mathrm{C}$ respectively; 5: Standard proteins.

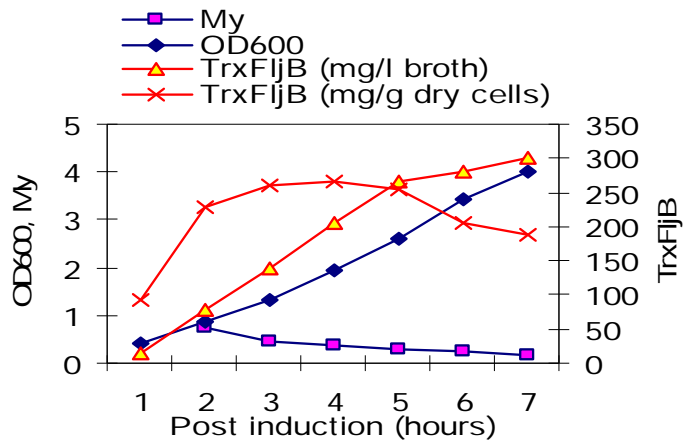

Fig. 4. Impact of post induction time on soluble TrxFljB production. My: growth rate.

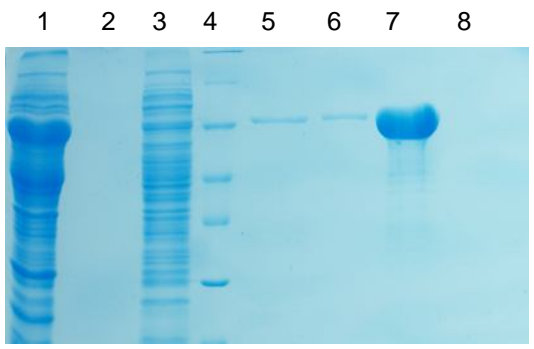

Fig. 6. Purification of TrxFljB

1: Crude protein solution was extracted from the strain harboring pET32fljB; 2: flow fraction; 3: wash fraction; 4: standard proteins; 5-8: elution fractions.

greatly influences the recombinant protein expression and can be harmful to cell growth. In the other hand, IPTG is an expensive substrate, 
thus in this work, the effect of a range of IPTG concentrations from 0 to $0.7 \mathrm{mM}$ on TrxFljB production was examined.

The growth rate of the strains was affected by storage duration at $4^{\circ} \mathrm{C}$. For the strain, which had been just transformed with plasmid pET32fljB and stored at $4^{\circ} \mathrm{C}$ for less than one week, IPTG concentration influenced strongly on the growth of the strain (fig. 3), in contrast to stored strain. The increased IPTG concentration reduced the cell biomass. Among the IPTG concentrations, the target protein was produced at the largest amount when the cells were induced with $0.1 \mathrm{mM}$ IPTG (Ca. $280 \mathrm{mg}$ TrxFljB/l broth). However, $0.05 \mathrm{mM}$ IPTG was sufficient to induce the $\operatorname{Tr} \mathrm{FFljB}$ production at reasonable high level $(\approx 270 \mathrm{mg} / \mathrm{l}$ broth $)$. The increase of IPTG concentration did not affect so much on specific TrxFljB productivity but reduced the yield of volumetric production (fig. 3 ). Thus, for the high level of volumetric production of soluble $\operatorname{TrxFljB}$, the freshly transformation strain should be induced with 0.05 or $0.1 \mathrm{mM}$ IPTG.

In contrary, different IPTG concentrations did not influence the growth of the strain, which was stored for one month at $4^{\circ} \mathrm{C}$ with 4 times of re-cultivation, but they affected on TrxFljB production (fig. 3). The total yield of TrxFljB was reached only $10 \%$ of the yield produced by freshly transformed strain.

\section{Post-induction time}

After adding IPTG into the medium, the target protein begins to be synthesized. However, the concentration of target protein is not proportional to the expression time because of the growth rate of the cells declining during cultivation without feeding carbon source. During the first two hours after induction, the strains were in growth phase (spectra of growth rates were declining from 0.7 to 0.5 ), and when the cells had been coming to stationary phase, the cells prioritized to accumulate the cells mass, concomitant with ribosome synthesis. Thus specific productivity of $\operatorname{TrxFljB}$ in this period was not high. However, 3 hours to 5 hours after induction, specific productivity of the protein reached to maximum and when the growth rate of the cells remained less than 0.3, TrxFljB production velocity was slowed down and reached $190 \mathrm{mg} / \mathrm{g}$ dry cells. The total yield of the proteins was $300 \mathrm{mg} / \mathrm{l}$ broth after 7 hours of induction. Overtime expression was counterproductive.

Impact of proteolysis on the TrxFljB productivity

E. coli posses many kinds of proteases. Although some of the genes coding for proteases were disrupted in industrial strains, but remaining proteases still play role in degradation of foreign protein, thus affect on the heterologous protein production.

To study in proteolysis of the target recombinant proteins, we used chloramphenicol $(0.1 \mathrm{mM})$ to inhibit protein synthesis in $E$. coli without any effect on protease activities. After adding chloramphenicol, the samples were taken every 30 minutes for protein analysis. As a result, after treatment with the chemical, the strain harboring pET32fljB did not increase the cells mass. At $3 \mathrm{~h}$ after chloramphenicol supplementation, a part of $\operatorname{TrxFljB}$ was degraded. The total yield was reduced from 310 $\mathrm{mg} / \mathrm{l}$ broth at the time of adding chloramphenicol to $200 \mathrm{mg} / \mathrm{l}$ broth after 3 hours.

In 2004, Lopez-Boado demonstrated that neutrophil elastase cleaved Salmonella flagellins at Ile-Ala, 50 residues from the $\mathrm{N}$ terminus and cathepsin $\mathrm{G}$ digested the flagellins at Asn-Ala, 54 residues from the $\mathrm{N}$ terminus. And these cleavages of flagellin resulted in inability to induce the expression of host defense genes in epithelial cells due to the loss of affinity for Toll-like receptor 5. Another study showed a successful expression of flagellin gene in $E$. coli in chimeric form with green fluorescent protein. This fusion protein was stable from protease activities in E. coli and had ability to stimulate maturation of APCs and secrete pro-inflammatory cytokines [3]. In this study, we also succeeded in expression of flagellin gene of $S$. Typhimurium in fusion form with thioredoxin. The recombinant protein was stable from protease activities.

\section{Purification of recombinant antigens}


TrxFljB has Hexa-histidine at $\mathrm{C}$ terminal. Thus, this protein was easily purified by HisTrap column chromatography. The purity of TrxFljB was $87 \%$ by VersaDoc Imaging system. The purified protein was used to immunize chickens for assessment on its antigenicity and immunogenicity in chickens. The results already published that TrxFljB had antigenicity as the same as natural flagellin. TrxFljB also induced antibody production in immunized chickens. The antibodies identified native flagella of $S$. Typhimurium cells [9]. We had produced the other flagellin of $S$. Typhimurium (FliC), flagellin of $S$. Enteritidis (FliC) and fimbrillin SefA of $S$. Enteritidis in $E$. coli by the same way $[6,7,8]$. Then, all these recombinant proteins were mixed together to inject into chickens. As a satisfactory result, anti-recombinant protein antibodies inhibited 10 times of $S$. Typhimurium growth and 4 times of $S$. Enteritidis growth comparing to control group [4]. The present results suggest that these proteins may promise for sub-unit vaccine development for defense chickens against $S$. Enteritidis, $S$. Typhimurium.

\section{CONCLUSION}

Flagellin FljB, which compose flagellar antigen $\mathrm{H}: 1,2$ of $S$. Typhimurium was overexpressed in E. coli under the fusion form with thioredoxin. The highest amount of soluble TrxFljB (about $300 \mathrm{mg} / \mathrm{l}$ broth) was achieved when the freshly transformed cells was cultivated in induction medium containing 0.1 $\mathrm{mM}$ IPTG, at $25^{\circ} \mathrm{C}$ until cell density reached to stationary phase.

\section{REFERENCES}

1. Barbezange C., Ermel G., Ragimbeau C., Humbert F., Salvat G., 2000. Some safety aspects of Salmonella vaccines for poultry: in vivo study of the genetic stability of three Salmonella typhimurium live vaccines. FEMS Microbiol. Lett., 192:101-106.

2. Chanter N., Jackson K., Pugh C., Sheehan B., 2006. Vaccination of laying chickens with an inactivated Salmonella vaccine reduces Salmonella growth in eggs. 13S
International Symposium Salmonella and Salmonellosis Proceedings Available at: http://hdl.handle.net/1854/LU-365946

[Accessed January 20, 2014].

3. Cuadros C., Lopez-Hernandez F. J., Dominguez A. L., McClelland M., Lustgarten J., 2004. Flagellin fusion proteins as adjuvants or vaccines induce specific immune responses. Infect Immun., 72:2810-2816.

4. Davies R., Breslin M., 2003. Effects of vaccination and other preventive methods for Salmonella enteritidis on commercial laying chicken farms. Vet. Rec., 153:673677.

5. Didierlaurent A., Ferrero I., Otten L. A., Dubois B., Reinhardt M., Carlsen H., Blomhoff R., Akira S., Kraehenbuhl J.P., and Sirard J.C., 2004. Flagellin promotes myeloid differentiation factor 88-dependent development of Th2-type response. J. Immunol., 172: 6922-6930.

6. Do T. H., Le Q. G., Van T. N. N., To L. T., Truong N. H., 2007. Overexpression of flagellin FliC originated from Salmonella Enteritidis in Escherichia coli under the chimeric form with thioredoxin. Journal of Science and Technology in Vietnam., 45: 195-203.

7. Đỗ Thị Huyền, Lê Quỳnh Giang, Nguyễn Thị Trung, Nguyễn Thị Nga, Nguyễn Thị Liên Hương, Phùng Đức Tiến, Tô Long Thành, Trương Nam Hải., 2008. Tính kháng nguyên và tính sinh miễn dịch của các protein tái tổ hợp có nguồn gốc từ kháng nguyên roi SefA của Salmonella typhimurium và $S$. enteritidis ở gà. Tạp chí Khoa học và Kỹ thuật Thú y, 15: 60-68.

8. Đỗ Thị Huyền, Lê Quỳnh Giang, Trần Ngọc Tân, Tô Long Thành, Trương Nam Hải, 2008. Biểu hiện SefA của Salmonella enterica serovar Enterititis trong Escherichia coli BL21. Tạp chí Công nghệ sinh học, 6: 175-182.

9. Đỗ Thị Huyền, Lê Quỳnh Giang, Văn Thị Như Ngọc, Tô Long Thành, Trương Nam Hải, 2008. Protein FliC của Salmonella 
Typhimurium biểu hiện mạnh trong $E$. coli dưới dạng dung hợp với Thioredoxin. Tạp chí Khoa học và Công nghệ, 46:49-57.

10. Đỗ Thị Huyền, Nguyễn Thành Trung, Nguyễn Thị Thu Hằng, Phạm Thúy Hồng, Trương Văn Dung, Trương Nam Hải, Lê Đình Lương, 2003. Phân lập và biểu hiện gen gm1 mã hóa epitope kháng nguyên H:g,m của Salmonella enteritidis ATTC13076. Tạp chí Di truyền và Úng dụng, 34-39.

11. Đỗ Thị Huyền, Nguyễn Thị Liên Hương, Phùng Đức Tiến, Lê Quỳnh Giang, Nguyễn Tiến Thành, Trương Thị Hương Giang, Trần Thị Hạnh, Tô Long Thành, Trương Nam Hải, 2008. Đánh giá tính an toàn, thuần khiết và hiệu lực của vaccine tái tổ hợp phòng Salmonella Typhimurium, $S$. Enteritidis trên gà. Tạp chí Khoa học và Kỹ thuật Thú y, 15: 28-37.

12. Ikeda J. S., Schmitt C. K., Darnell S. C., Watson P. R., Bispham J., Wallis T. S., Weinstein D. L., Metcalf E. S., Adams P., O'Connor C. D., O'Brien A. D., 2001. Flagellar phase variation of Salmonella enterica serovar Typhimurium contributes to virulence in the murine typhoid infection model but does not influence Salmonellainduced enteropathogenesis. Infect. Immun., 69: 3021-3030.

13. Nagashima K., Kubota Y., Shibata T., Sakaguchi C., Shinagawa H., Hishida T., 2006. Degradation of Escherichia coli $\mathrm{RecN}$ aggregates by ClpXP protease and its implications for DNA damage tolerance. J. Biol. Chem., 281: 30941-30946.

14. Sambrook J., Russell D. W., 1989. Molecular cloning: a laboratory manual. Second edition. New York: Cold Spring Harbor Laboratory Press.

15. Sinha K., Mastroeni P., Harrison J., Hormaeche R. D. de, Hormaeche C. E.,
1997. Salmonella typhimurium aroA, htrA, and aroD htrA mutants cause progressive infections in athymic (nu/nu) BALB/c mice. Infect. Immun., 65: 1566-1569.

16. Sotomayor E. M., Suarez I., 2008. Flagellinbased adjuvants and vaccines. Patent number US 7404963 B2.

17. Toyota-Hanatani Y., Inoue M., Ekawa T., Ohta H., Igimi S., Baba E., 2008. Importance of the major FliC antigenic site of Salmonella enteritidis as a subunit vaccine antigen. Vaccine., 26: 4135-4137.

18. Toyota-Hanatani Y., Kyoumoto Y., Baba E., Ekawa T., Ohta H., Tani H., Sasai K., 2009. Importance of subunit vaccine antigen of major Fli C antigenic site of Salmonella enteritidis II: a challenge trial. Vaccine., 27: 1680-1684.

19. Urech C., Koby S., Oppenheim A. B., Münchbach M., Hennecke H., Narberhaus F., 2000. Differential degradation of Escherichia coli sigma32 and Bradyrhizobium japonicum RpoH factors by the FtsH protease. Eur. J. Biochem., 267: 4831-4839.

20. Vo A. T. T., van Duijkeren E., Fluit A. C., Heck M. E. O. C., Verbruggen A., Maas H. M. E., Gaastra W., 2006. Distribution of Salmonella enterica serovars from humans, livestock and meat in Vietnam and the dominance of Salmonella Typhimurium phage type 90. Vet. Microbiol., 113:153158.

21. Vries D. N., Zwaagstra K. A., Huis in't Veld J. H., van Knapen F., van Zijderveld F.G., Kusters J. G., 1998. Production of monoclonal antibodies specific for the $i$ and 1,2 flagellar antigens of Salmonella typhimurium and characterization of their respective epitopes. Appl. Environ. Microbiol., 64: 5033-5038. 


\title{
BIỂU HIỆN FLAGELLIN FljB CỦA Salmonella enterica serovar Typhimurium TRONG Escherichia coli BL21
}

\author{
Đỗ Thị Huyền, Lê Quỳnh Giang, Trương Nam Hải
}

Viện Công nghệ sinh học, Viện Khoa học và Công nghệ Việt Nam

\section{TÓM TÁT}

Flagellin FljB là thành phần cấu thành nên kháng nguyên roi (H:1,2) của $S$. Typhimurium. Kháng nguyên này có khả năng kích thích làm tăng sinh đáp ứng miễn dịch trong cơ thể động vật, vì vậy, có thể sử dụng trong việc phát triển vaccine. Gen $f l j B$ (1515 nucleotide) mã hóa cho FljB chức năng đã được khuếch đại bằng PCR từ DNA genome $S$. Typhimurium và chuyển vào vector $\mathrm{pET} 32 \mathrm{a}(+)$ để biểu hiện gen này trong Escherichia coli BL21. Protein FljB đã được biểu hiện tốt trong E. coli dưới dạng dung hợp với Trx, S-tag ở phía đầu $\mathrm{N}$ và hexahistidine ở đầu $\mathrm{C}$, vì vậy mà được gọi tắt là TrxFljB. Nghiên cứu về ảnh hưởng của nhiệt độ lên sự biểu hiện của gen $f l j B$ đã cho thấy, lượng TrxFljB được tổng hợp ở $37^{\circ} \mathrm{C}$ thấp hơn so với lượng được tổng hợp ở $22^{\circ} \mathrm{C}$ và $25^{\circ} \mathrm{C}, 13 \%$ protein tổng hợp ở $37^{\circ} \mathrm{C}$ là dạng thể vùi (inclusion body). Nuôi cấy cảm ứng tế bào ở nhiệt độ thấp đã làm tăng khả năng tan của protein tái tổ hợp (khoảng $97 \%$ protein TrxFljB được tổng hợp ở $25^{\circ} \mathrm{C}$ là dạng tan). Nồng độ IPTG ảnh hưởng mạnh lên khả năng sinh trưởng của chủng tái tổ hợp mới được biến nạp nhưng lại không ảnh hưởng đến chủng tái tổ hợp đã được giữ và được cấy chuyển. Nồng độ IPTG tăng lên làm cho chủng mới được biến nạp sinh trưởng yếu hơn, do đó làm giảm hiệu suất tổng hợp TrxFljB. Lượng TrxFljB tối đa đạt được (khoảng $280 \mathrm{~g} / \mathrm{l}$ môi trường nuôi cấy) khi chủng mới biến nạp được nuôi cấy cảm ứng với $0,05 \mathrm{mM}$ IPTG. Lượng TrxFljB từ chủng giữ ở $4^{\circ} \mathrm{C}$ và cấy chuyền nhiều lần cũng bị giảm đáng kể. Ở điều kiện tối ưu, sản lượng TrxFljB tối đa thu được từ chủng mới được biến nạp là khoảng $300 \mathrm{mg} / 1$ môi trường nuôi cấy.

Keywords: Escherichia coli BL21, S. typhimurium, fljB, pET32a(+), protein tái tổ hợp.

Ngày nhận bài: 12-4-2014 